\title{
Listy i dziennik Anny Moszyńskiej: awers rozmowy, rewers szaleństwa
}

\begin{abstract}
K $\quad$ r $y$ t $y$ K i : Anna Moszyńska. Listy z Pirny, 1850. Uzupetnione fragmentami dziennika oraz listami Piotra Moszyńskiego, oprac. Emilia Kolinko, Wydawnictwo IBL PAN, Warszawa 2018
\end{abstract}

Dokumenty osobiste publikowane w serii Archiwum Kobiet to wyjątkowe przedsięwzięcia edytorskie i wydawnicze. Autorki opracowań, które odnalazły i odczytały dziewiętnastowieczne rękopisy, opatrzyły je wstępami, biografiami, kalendariami, aneksami, komentarzami, zrezygnowały z modernizacji zapisów i innych edytorskich ingerencji, zachowując wszelkie ,indywidualne cechy osoby piszącej: nawyki językowe, wahania pióra, umiejscowienie dopisków"1. Listy, dzienniki, pamiętniki kobiety były dotychczas słabo reprezentowane i zwykle pomijane w historiografii i historii literatury bądź istniały w okrojonych wersjach. Na długie lata ich zapiski utknęły i tkwią nadal w archiwach oraz bibliotekach. Druga publikacja w tej innowacyjnej serii, którą rozpoczęła Bronisława Waligórska. Listy z cytadeli, 1886 przygotowana przez Monikę Rudaś-Grodzką, to korespondencja i dia-

\footnotetext{
${ }^{1}$ M. Prussak, Edycja dokumentacyjna. Zasady wydania, [w:] Bronisława Waligórska. Listy z cytadeli 1886, ancilla libri M. Rudaś-Grodzka, Warszawa 2018, s. 7. Moim zdaniem druk nie jest całkiem „formą bezosobową” (tamże), ponieważ nawet liternictwo i projekty typograficzne odzwierciedlają decyzje osobiste i/lub polityczne. Zob. A. Szydłowska, Od Solidarycy do TypoPolo. Typografia a tożsamości zbiorowe w Polsce po roku 1989, Wrocław 2018; A. Szydłowska, M. Misiak, Paneuropa, Kometa i Hel. Szkice z historii projektowania liter w Polsce, Kraków 2015.
}

riusz Anny Moszyńskiej odkryte przez Emilię Kolinko. W obydwu książkach została przywrócona głęboka relacja między czasem teraźniejszym i przeszłością oraz realnością, a w przypadku Moszyńskiej również z dramatycznym zjawiskiem choroby psychicznej. Oznacza to, że sytuacja, w której żyła i pisała Moszyńska, wróciła do nas i możemy odczytywać (jej) historię bezpośrednio w oryginalnej formie niewygładzonego, niepoprawionego tekstu. Mamy sposobność poznawać (analizować i interpretować) tekst, który jest filologicznie wierny minionej rzeczywistości i prawdziwy, tzn. niezamknięty w arbitralnie ustalonej, czyli zmienionej/unowocześnionej postaci nadanej mu przez edytora².

Edycja zachowująca rękopiśmienny kształt dokumentu, bliski autentycznej formie zapisu (z zaznaczonymi w druku przekreśleniami, zmazaniami, uzupełnieniami, odwróceniami), przywraca „możliwość zapoznania się z tym, co w tekście jest nienormatywne, co odbiega od konwencji albo nawet ją narusza"3. Pomysł wydawniczy

\footnotetext{
${ }^{2}$ O krzyżujących się, a zarazem też zbieżnych drogach filologów i edytorów pisała M. Prussak, My, filologowie, [w:] Tożsamość tekstu. Tożsamość literatury, red. P. Bem, Ł. Cybulski, M. Prussak, Warszawa 2016, s. 7-8.

${ }^{3}$ M. Prussak, Edycja dokumentacyjna..., dz. cyt., s. 7.
} 
ściśle wpisuje się w działalność Zespołu Archiwum Kobiet IBL PAN, którego baza gromadzi dane dotyczące niepublikowanej autobiografistyki, zawierającej ogrom cennych dokumentów scalających wymiary osobiste i społeczno-polityczne. Celem Archiwum jest uzupełnienie sfery polskiej kultury, czyli wprowadzenie do niej zapomnianych czy też wykluczonych głosów kobiet. Z tego zaginionego rejestru dźwięków teraz wyłoniła się Moszyńska, zamknięta wręcz w dwojaki sposób: z powodu braku zainteresowania badawczego i przyczyny własnej choroby, która skazywała ją na milczenie - została umieszczona w zakładzie dla obłąkanych, a mąż zapewniał ją, że będzie codziennie otrzymywała listy lub ustne wiadomości od niego i dzieci, ale jednocześnie odradzał, aby sama zbyt często pisała, gdyż ten trud umysłowy mógłby jeszcze bardziej jej zaszkodzić.

Emilia Kolinko zaznacza, że znalazła korespondencje i dziennik Moszyńskiej w zbiorach Biblioteki Narodowej w Warszawie. Wspomina w Nocie edytorskiej, że dokumentacja medyczna dotycząca jej bohaterki oraz część prywatnych listów Moszyńskich została przekazana z krakowskiej składnicy makulatury do biblioteki w 1989 roku. Przygotowując książkę, podzieliła ją na kilka zwartych elementów (z osobną numeracją stron) i tom składa się z: korpusu sześćdziesięciu listów Anny Moszyńskiej do męża (połowa), dzieci, przyjaciółek, służącej i innych osób oraz dwóch falsyfikatów (Moszyńska napisała te listy do męża, podając się za swojego lekarza), dwóch notatników diarystycznych Moszyńskiej; Dodatki mieszczą kilka różnych listów (od córki, pasierbicy przyjaciółek do Anny, dwa listy Piotra do różnych adresatów); w Aneksach badaczka umieściła dokumentacje choroby Anny Moszyńskiej i listy lekarzy do jej męża; na końcu znajdują się listy Piotra Moszyńskiego do żony. Taka całość dokumentacyjna została opatrzona szczegółowym Kalendarium i wnikliwym Wstępem, na podstawie których możemy odtworzyć dzieje życia i choroby Moszyńskiej. Wielostronne analizy Kolinko dotyczące Anny Moszyńskiej, jej rodziny, rodziny męża, a także wiele informacji o przyjaciołach i znajomych Moszyńskich (dodatkową pomoca jest tu Słownik biograficzny) oraz rozbudowane konteksty historyczne połowy XIX wieku, w tym dokładne opisy klinik dla chorych psychicznie i ówczesnych warunków oraz metod leczenia, skrupulatne i ciekawe przypisy, reprodukcje fotografii, listów, rysunków i inne ilustracje, jak również zaangażowanie badawcze autorki powodują, że lektura jest fascynującym zajęciem, choć też przytłaczającym z powodu pesymistycznej tonacji tych egodokumentów.

Anna Moszyńska (1820-1889), z domu Malinowska, urodziła się na Wołyniu w rodzinie szlacheckiej. Po śmierci rodziców Anną i jej rodzeństwem zaopiekowali się krewni. Trafiła do majątku Sobańskich, gdzie mieszkała Józefa Moszyńska i została jej panną do towarzystwa. Razem wyjechały do Czernihowa, do ojca Józefy, Piotra Moszyńskiego, który później został mężem Anny. Moszyński wrócił w 1934 roku z zesłania na Syberię, skazany za działalność w Towarzystwie Patriotycznym. Po aresztowaniu i przymusowym wyjeździe Piotra jego pierwsza żona związała się z oficerem litewskim, ale to Moszyńskiemu po powrocie z Tobolska przyznano opiekę nad córką. Po rozwodzie poprosił o rękę młodszą o dwadzieścia lat Annę Malinowską. Ich ślub obył się w Kijowie w 1839 roku. Moszyńscy zamieszkali z Józefą w Dolsku na Wołyniu. Anna urodziła w 1840 roku pierwszą córkę Julię, która niedługo potem zmarła. Moszyńska zapadła w śpiączkę, chorowała, następnie te objawy i wcześniejsze dziewczęce przypadłości (blednica, omdlenia, drżenie kończyn, nerwowość) były kojarzone z jej poważniejszymi zaburzeniami umysłowymi; ponadto kobiety w rodzinie Malinowskich wykazywały skłonności do popadania w melancholię, a starsza siostra Idalia została zdiagnozowana jako nimfomanka. W 1842 roku rodzi się córka Zofia. Moszyńscy przeprowadzają się do Krakowa, gdzie Anna angażuje się w działalność 
dobroczynną, m.in. współtworzy pierwszą krakowską ochronkę dla dzieci. Pojawiają się kolejne dzieci: Emanuel i Maria. W 1846 w mieście wybucha powstanie i w tym czasie Anna pisze wizyjny tekst pt. Uczucia i widzenia Polki w roku 1846, opublikowany anonimowo przez Piotra Moszyńskiego w 1850. Zaczyna chorować psychicznie, wykazując „niezdrową skłonność do mistycyzmu i ascetyzmu, nadmierną religijność [...], wyraża pragnienie zachowania czystości i odwrócenia się od świata"“ (Kalendarium, s. 27). Jej stan poprawia się po podróży wzdłuż Renu, jest znowu w ciąży i rodzi w 1947 roku syna Jerzego, następnie zapada na zdrowiu i popada w manię. Cierpi na bezsenność, miewa ataki furii, odmawia przyjmowania lekarstw i jedzenia. W 1948 wyjeżdża z mężem na kurację do Marienbadu. Po jej zakończeniu Moszyńscy zatrzymują się w Ostendzie, Paryżu i Londynie. W 1949 w Krakowie na świat przychodzi córka Helena. Latem Anna przebywa w Kolonii i widok tamtejszej katedry wywołuje w niej silne wzruszenia duchowe. W Szwajcarii spotyka matkę swojej zmarłej, idealizowanej przyjaciółki Eleonory Karwickiej, ostatecznie samopoczucie psychiczne i fizyczne Anny gwałtownie się pogarsza. Moszyński zabiera ja ponownie do Marienbadu, lecz tym razem zabiegi lecznicze nie przynoszą żadnej poprawy. Rodzina spędza zimę w Dreźnie wraz z przyjaciółmi i dalszymi krewnymi. Jeden z gości Moszyńskich notuje wtedy w pamiętniku, że Anna zupełnie zwariowała i rodzą się obawy, że może kogoś zabić albo podpalić dom. Z początkiem lutego 1850 roku Piotr zawozi żonę do pobliskiego zakładu dla obłąkanych w Pirnie. Odtąd Moszyńska staje się wieloletnią pacjentką szpitali dla chorych umysłowo. W prywatnym pirneńskim Zakładzie Leczenia i Opieki Królestwa Saskiego spędza pół roku. Następnie w sierpniu tra-

\footnotetext{
${ }^{4}$ Anna Moszyńska. Listy z Pirny, 1850. Uzupełnione fragmentami dziennika oraz listami Piotra Moszyńskiego, oprac. E. Kolinko, Warszawa 2018, s. 43. Dalej podaje w nawiasach tytuły rozdziałów i części książki oraz numery stron.
}

fia do szpitala w Leubus (obecnie Lubiąż), skąd po trzech miesiącach wyjeżdża do rodzinnego pałacu Moszyńskich w Krakowie. Po powrocie do domu przebywa również przez pewien czas w krakowskim Szpitalu Świętego Ducha, aż ponownie w 1851 roku zostaje umieszczona w Leubus, gdzie leczy się do 1875. Cztery lata później opuszcza zakład, mieszka do swojej śmierci z synem Jerzym w Łoniowie; jej mąż Piotr umarł w 1879 roku, ona dziesięć lat później.

W połowie lutego 1850 roku, w trakcie pobytu w pirneńskiej klinice, Anna zaczęła prowadzić dziennik, wkrótce potem także korespondencję. Jej listy i dwuczęściowy diariusz to świadectwa „obecności głosu i braku głosu” (Wstęp, s. 43), stwierdza Emilia Kolinko: „Anna Moszyńska pisała, by zaistnieć, dać wyraz swojej egzystencji, w jej emocjonalnym i intelektualnym znaczeniu". Te dwa, prowadzone równolegle, osobiste dokumenty są także „chaotyczną wiązką wielu głosów, wielu autonarracji (dialogi, opowiastki dla dzieci, szkice literackie, wspomnienia) [...]. Raz przyznaje się Anna do choroby, innym razem jej zaprzecza; raz jest zadowolona ze swojej krnąbrności, by za chwilę się spłoszyć, przysięgać mężowi uległość i posłuszeństwo; zniechęcona i zła, chce przestać pisać do Piotra, ale w końcu kapituluje, sięga po pióro, potrzeba pisania o sobie jest zbyt silna" (Wstęp, s. 52-53).

Jednak Moszyńska nie widziała sprzeczności między tymi głosami, które wybrzmiewają w jej korespondencji i dzienniku. Może dlatego, że traktowała swoje pisanie jak polifoniczną spowiedź albo raczej samą siebie spostrzegała jako metamorficzne połączenie kilku postaci: kobiety i mężczyzny, kobiety i dziecka, matki, sieroty, hermafrodyty, mesjanki, patriotki, prorokini... W pierwszej części diariusza zapowiada, że zamierza się wyspowiadać przed Piotrem, a wyznanie grzechów zawsze było dla niej „wielkim cierpieniem połączonym z niewypowiedzianą pociechą" (Dziennik I, s. 6). On jest spowiednikiem, ona cierpiąca duszą (Listy, s. 175). Mo- 
szyńska przywołuje wcześniejszy list, w którym rozpoczęła proces wyjawiania grzechów i tajemnic, określając swoją rolę: posłusznej siostry, córki, dziecięcia (Listy, s. 96), być może dlatego, że wcześniej napisała: „tobie mój Drogi przysięgłam w obliczu Boga posłuszeństwo i wiarę małżeńską [...] Ale uważaj dobrze mój drogi Piotrze że to jest posłuszeństwo małżeńskie a nie, nieograniczone, które kobiety mężom przy Ślubie przysięgają; to nie jest te wyrzeczenie się woli własnej" (Listy, s. 94) . W zapiskach porównuje się do osamotnionego dziecka, które zaczyna zdobywać samodzielność i dziwi się światu, nie znajdując w nikim ani nigdzie wsparcia. Słyszy tylko karcące zdania: „Ja ci mówiłam, Piotrze, kochaj mnie, a tyś mi na to zawsze odpowiadał, tyś chora, ja wołałam do ciebie, Piotrze, miłości! A tyś mnie lekarstwami poił. Aż na koniec niestało niewiem czego, podobno cierpliwości, o Boże! Piotrze mój, przepraszam was zato" (Dziennik I, s. 7-8).

Piotr, przypominając jej godny pożałowania stan, w jakim znajdowała się przedtem, napomina żonę w liście: „Zaklinam Cię więc na wszystko co ci jest świętém żebyś bez oporu we wszystkiém słuchała przepisów Pana Pienitza i Ditrych bo tylko od scisłego wypełnienia nawet najmniejszych rad zależy twój powrót zupełny i ustalenie na przyszłość zdrowia twego a tém samém połączenie się nasze" (Piotr Moszyński. Listy do Anny Moszyńskiej, 1850, s. 3).

Listy wymieniane między małżonkami tworzą dziwny dwugłos, każde z nich inaczej widzi i pamięta to, co się zdarzyło i co się dzieje. Moszyński utrzymuje, że choroba żony jest uwarunkowana słabością ciała i ma nadzieję, iż zostanie wyleczona. Moszyńska jest twierdzi, że wcale nie jest chora (ewentualnie, że ognisko jej „schorzenia” to serce), nie zgadza się na pobyt w klinice, zwykle odmawia przyjmowania lekarstw, więc często zmuszano ją do połykania tabletek, wiązana w kaftan podczas maniakalnych napadów, kiedy niszczy przedmioty. Zachowuje się agresywnie wobec personelu i dokonuje samookaleczeń. Anna sfałszowała dwa listy do Piotra, podszywając się pod dyrektora kliniki - jako doktor Ernst Pienitz informuje Moszyńskiego, że stan zdrowia jego żony jest lepszy i można ją zabrać do domu. Piotr oczywiście od razu orientuje się i znowu ją upomina. Istnieją jeszcze inne świadectwa z tego czasu: korespondencja Moszyńskich z przyjaciółmi i krewnymi, listy wymieniane między lekarzami i Piotrem, a także zapisy przebiegu choroby Moszyńskiej sporządzone przez doktora Antona Dietricha w Pirnie i doktora Friedricha Hoffmanna w Leubus. W dokumentacji medycznej powtarzają się opisy furii, których przebieg łączono z cyklem menstruacyjnym, próby podporządkowania sobie personelu, wiara chorej we własne nadprzyrodzone siły, urojenia religijne i poglądy komunistyczne, zatwardzenia, rozwolnienia, bezsenność, gorączkowość, gadulstwo, złośliwość, napady podniecenia seksualnego, obnażanie się, masturbacja. Drugi opis jest dłuższy i dodatkowo uwzględnia tło rodzinne, w tym występujące w rodzinie zaburzenia psychiczne, kontekst polityczny, czyli oddziaływanie burzliwych wydarzeń społecznych na samopoczucie pacjentki, przebieg poszczególnych ciąż i okresów karmienia piersią, opis ciała oraz wyglądu narządów płciowych, zainteresowanie mistycyzmem i magnetyzmem, spacery boso po pokoju i na zewnątrz, niezważanie na konwenanse, nieprzestrzeganie regulaminu ośrodka, brak tolerancji, historię leczenia wcześniejszych ekstaz i melancholii w Marienbadzie, utożsamianie się z Chrystusem na krzyżu, a także z hermafrodytą, który może zapłodnić sam siebie. Figura dwupłciowa ma zapewne związek z wyobrażeniami Anny o sobie, czuła, że jest kimś więcej niż kobietą, a mniej niż mężczyzną - „o tak, jakieś ono jakieś coś” (Listy, s. 176). Według lekarzy Moszyńska oceniała błędnie swój stan, nie uznając swojej choroby; ona uważała, że jej wzburzenie wynika z oporu, jaki słusznie stawiała, będąc uwięzioną wbrew własnej woli. A w czasie dobrego samopoczucia jest ironiczna i sceptyczna, nazywając siebie „Królową Wariatów” (Dziennik I, s. 24). 
Niemożliwe byłoby znalezienie punktu wspólnego w trzech relacjach: listach Anny do męża i dzieci, listach Piotra i medycznych sprawozdaniach (ona jest poetycka, on przyzwoity, a raporty suche), lecz bardziej zastanawia mnie akt spowiedzi w dokumentach osobistych Moszyńskiej, który Emilia Kolinko określiła jako konieczność i zarazem działanie chybione, skazane na porażkę, ponieważ Moszyńska nie doczekała się rozgrzeszenia, a tylko bezustannie konfrontowała się z opiniami męża i lekarzy, którzy negowali jej prawdę o sobie samej i uznawali jej zachowania za patologiczne (Wstęp, s. 54), nawet te ekscesy, które były tylko ekscentryczne. Prawdopodobnie również i z tego powodu zidentyfikowała się z Ukrzyżowanym. W diariuszu (Dziennik I, s. 35-36) oraz w przedostatnim liście Moszyńska zapisała Sen Maryi Eleonory. Jest to historia dziewczynki, która wychodzi z domu, błąka się po lesie, zrywa kwiatki, potem plecie wieniec z cierniowych gałązek i wkłada na głowę. Odłamuje z niego kolec i przebija stopę. Pojawia się Ojciec, który kładzie ją na ziemi, wbija ciernie w jej ręce i kończy krzyżowanie. Dziewczynkę budzi ze snu brat i okazuje się, że ból był spowodowany tym, że chłopiec ukłuł ją, przypinając bukiecik fiołków do sukienki (Listy, s. 219-221). Dowodzi to bezsilności Moszyńskiej, podsumowuje Kolinko, „uciekała się [ona] do dolorystycznej symbolizacji, bo męka oznaczała, że cierpienie zostanie nagrodzone, ale dopiero w przyszłości, dopiero po śmierci" (Wstęp, s. 67). W rzeczywistości, budząc się, pozostawała w pogłębiającej się izolacji. Ale ciągle walczyła o siebie, z nikim się nie zgadzała, choć czasami udawała pokorną, więc może w miejscu tradycyjnego wątku oddzielającego (doczesny) ból przegranej sprawy od (pośmiertnego) triumfu udałoby się dostrzec motyw przetransponowany z Pieśni koptyjskiej Goethego - skoro w świecie stoimy przed wyborem bycia kowadłem lub młotem, to chyba w którymś momencie warto spróbować jednego i drugiego naraz. Rozleglejszy kontekst martyrologiczny, czyli mękę narodu polskiego/męczeństwo
Chrystusa, autorka opracowania omawia we wcześniejszym rozdziale Od martyrologii narodu do komunizmu i walki słowem miłości, analizując głównie tekst napisany przez Moszyńską Uczucia i widzenia Polki... (Wstęp, s. 61-65).

Przypuszczam, że autobiograficzne wyznanie nie jest w przypadku Moszyńskiej tym samym, co przyznanie się do czegoś ${ }^{\text {. Anna } w}$ listach i dzienniku przedstawia wielogłosową prawdę o sobie (jednocześnie nie możemy tej prawdy oddzielić od jej psychicznych zaburzeń). Moszyński i lekarze chcą, żeby przyznała się do choroby, poddała leczeniu i wróciła do poprzedniej zdrowej formy: kobiety, żony, matki, Polki, katoliczki. Dlaczego dopiero choroba skłoniła ją do mówienia prawdy o sobie samej, która jest w części szalona, częściowo w romantycznym stylu subwersywna i całkowicie przygnębiająca? Wydaje się, że obecność Moszyńskiej niknie w rzeczywistości, mimo że jej zmieniająca się postać jest ciągle widoczna, to trudno ją rozpoznać w jakimś określonym albo jednolitym wizerunku. Destrukcja nadaje nowe kształty ${ }^{6}$ - przejawia się m.in. w tym, że Anna wymyśla

\footnotetext{
${ }^{5}$ M. Foucault rozpoczyna cykl swoich wykładów w Louvain od przypomnienia metody francuskiego psychiatry François Leureta (1840), który, oblewając lodowatą wodą pacjenta cierpiącego na manię prześladowczą i halucynacje, wymusza na nim przyznanie się do choroby: „napotykamy tu ideę, którą można odnaleźć w całych dziejach psychiatrii: nie można jednocześnie być szalonym i mieć świadomość bycia szalonym - dostrzeżenie prawdy powoduje, że obłęd znika. I wśród wszystkich terapii stosowanych przez wieki w leczeniu szaleństwa można znaleźć tysiące środków czy podstępów wymyślonych, by chory uświadomił sobie swe szaleństwo. [...] To, czego chce [Leuret], to określony akt, potwierdzenie: «Jestem szalony». Wyznanie - decydująca stawka w terapeutycznym działaniu" (tegoż, Zło czynić, mówić prawdę. Funkcja wyznania w sprawiedliwości. Wykłady z Louvain, 1981, oprac. F. Brion, B.E. Harcourt, przeł. A. Zawadzki, Kraków 2018, s. 21).

${ }^{6}$ Zdarza się, że w następstwie chorób, wypadków, traumatycznych przeżyć albo bez żadnego powodu tożsamość ulega radykalnej metamorfozie: „tor się rozwidla i nowa osobowość, bez precedensu, współzamieszkuje z dotychczasową, zajmując w końcu całą przestrzeń dla siebie. Jest to osobowość nie do poznania, której teraźniejszość nie wypływa z żadnej przeszłości i której przyszłość pozbawiona jest jutra; absolutna improwizacja egzystencjalna. Forma z wypadku zrodzona, przez przypadek powstała; rodzaj przypadłości" (C. Malabou, Ontologia przypadłości. Esej o plastyczności destrukcyjnej, przeł. P. Skalski, Warszawa 2017, s. 8).
} 
sobie kolejne imiona (Helenka, Maria Eleonora, Ânn etc.), odgrywa rozmaite role, kryje twarz za maskami transformacyjnymi , zasłania się i odsłania, konstruując epistolarne/diariuszowe opowieści i przypowieści o sobie. W konsekwencji zerwanie z dawną sobą poskutkowało przeistoczeniem się, może ponownymi bądź ponawiającymi się narodzinami. Chyba właśnie dlatego jedną z ważnych figur w listach i dzienniku jest dziecko, z którym się utożsamia. Jego potencjał emancypacyjny i transformacyjny jest prawdopodobnie największy, tak jakby dzieciństwo zawierało pierwotną przyszłość. Czy te wszystkie metamorfozy były wrodzone, czy przypadkowe? Jak długo trwały? Nie znamy dalszych losów Moszyńskiej ani żadnych jej późniejszych dokumentów osobistych, które pochodziłyby z okresu po opuszczeniu kliniki w Leubus. Nie wiadomo, czy znajdują się jeszcze gdzieś w archiwach rodzinnych lub instytucjonalnych.

Ostatni rozdział Wstępu nosi tytuł Moszyńska jako tekst i Emilia Kolinko, parafrazując zdanie Foucaulta, napisała: „Nie ma obłędu tam, gdzie jest prywatny głos" (s. 76). W zakończeniu, jednak nieco zbyt skrótowym, badaczka zastanawia się nad istotną konfiguracją: głosu, obłędu i czasu, czyli dawnymi i współczesnymi rytuałami „ekskluzji i inkluzji szaleńca"8 , które analizował francuski filozof. A zatem, jakim tekstem jest Moszyńska,

\footnotetext{
7 „Maski transformacyjne nigdy nie pozwalają zobaczyć maskowanej twarzy. Nie są zresztą dopasowane do twarzy, nie traktują jej jako modelu i nie służą do tego, by ją udawać. Otwierając się i zamykając, ukazują i chowają tylko inne maski. [...] Lévi-Strauss chwali ich «natchniony dar syntezy», zdolność łączenia elementów heterogenicznych. Tym, co pokazują, nie jest przebranie nałożone na oblicze, lecz stosunki transformacyjne, które nadają strukturę każdemu obliczu (ukazywanie i chowanie innych oblicz); w ten sposób maski te odsłaniają ukrytą więź, jaka istnieje między formalną jednością i powiązaniem, między pełnią określonej formy i możliwością jej rozbicia" (C. Malabou, Plastyczność u zmierzchu pisma. Dialektyka, destrukcja, dekonstrukcja, przeł. P. Skalski, Warszawa 2018, s. 10).

${ }^{8}$ M. Foucault, Szaleństwo, nieobecność dzieła, przeł. T. Komendant, [w:] tegoż, Powiedziane, napisane. Szaleństwo i literatura, wybór i oprac. T. Komendant, przeł. B. Banasiak, T. Komendant, M. Kwietniewska, A. Lewańska, M.P. Markowski, P. Pieniążek, Warszawa 1999, s. 154.
}

jaki konkretnie jest jej głos i jakiż to rodzaj obłędu? Kolinko uważa, że Moszyńska przeistoczyła się w tekst, który jest już zamknięty. Ale rzeczywistość, która minęła i życie, które stało się niewyraźną biografią, zjawiają się nieoczekiwanie przed nami. Korespondencja i diariusz z Pirny to punkty dojścia, „w zbiorze tym spotykają się wszystkie głosy: więźniarki-wariatki, córki, siostry, żony, matki, przyjaciółki i pisarki” (s. 76). Dzieło pt. Moszyńska powstało „na styku liryki i nauki”, uzupełniając „brak głosów tych, u których zdiagnozowano obłęd, trzymanych w zakładach i ukrywanych wstydliwie w prywatnych domach" (s. 77) ${ }^{9}$.

Właściwie tak. Ale teksty Moszyńskiej są przede wszystkim rozmową z Piotrem, czyli próbą wyartykułowania siebie i wyróżnienia własnego dźwięku spośród innych, które rozbrzmiewają głośno i stają się opresyjne. I to jest partia tytułowa Anny. Dość skutecznie przerywana wystąpieniami pozostałych wykonawców rodzinnego i społeczno-obyczajowego dramatu. W jej listach i dzienniku zarazem łatwo, jak i trudno wyznaczyć granicę między normalnością i chorobą, jest to raczej strefa sąsiedztwa ${ }^{10}$, więc uznałam, że dwugłos Anny i Piotra Moszyńskich jest monetą koszmarnych snów i nadal krąży w świecie - jej awersem jest dialog, a rewersem szaleństwo.

\footnotetext{
${ }^{9}$ Świadectwo takich głosów, a także istnienie masek choroby zostały odnotowane w autobiografistyce, autofikcjach i sztuce, zob. np. Maski, wybór, opracowanie i redakcja M. Janion, S. Rosiek, t. 2, s. 211-214, 245-276. Zob. też m.in. C. Lavant, Zapiski z domu wariatów, przeł. M. Łukasiewicz, Wrocław 2017; E. Ostrowska, Oto stoję w deszczu ciała (dziennik studentki), Warszawa 2013; O. Hund, Psy ras drobnych, Kraków 2018.

${ }^{10}$ Termin G. Deleuze'a, który definiuje pisanie jako stawanie się (kimś, czymś) i nie identyfikuje tego procesu z czekaniem na formę, lecz znajdowaniem „strefy sąsiedztwa” (tegoż, Krytyka i klinika, przeł. B. Banasiak, P. Pieniążek, Łódź 2016, s. 6). Celem pisania jest, według filozofa, „uwolnienie w obłędzie [...] kreacji zdrowia [...], to znaczy możliwości życia” (tamże, s. 11).
} 


\title{
SŁOWA KLUCZOWE:
}

edycje rękopismienne

\section{CHOROBA PSYCHICZNA}

\begin{abstract}
AbStrakT:
Omówienie książki Anna Moszyńska. Listy z Pirny, 1850. Uzupetnione fragmentami dziennika oraz listami Piotra Moszyńskiego, którą opracowała Emilia Kolinko. Tekst zawiera rozpoznanie kierunku zarysowującego się w nowatorskim edytorstwie (zachowującym rękopiśmienny kształt dokumentów osobistych), związków tej tendencji z różnymi praktykami filologicznymi oraz krótki opis założeń serii wydawniczej Archiwum Kobiet. W recenzji sformułowane zostały m.in. pytania dotyczące związków między dziełami autobiografistyki a szaleństwem i wykluczeniem kobiet autorek. Wśród innych zagadnień pojawiają się tematy przywracania głębokiej relacji między czasem przeszłym, teraźniejszym i realnością w egodokumentach oraz towarzyszących im pracach (biografiach, kalendariach, komentarzach).
\end{abstract}




\section{NOTA O AUTORZE:}

Iwona Misiak - dr, historyczka literatury, IBL PAN. W obszarze jej głównych zainteresowań badawczych znajduje się literatura polska XX wieku, ze szczególnym uwzględnieniem poezji pokolenia '68. Autorka książek Zmyst czytania (2003) i Poczq̨tek zagadki. O labiryntowej twórczości Ryszarda Krynickiego (2015). Współpracuje z Uniwersytetem Kardynała Stefana Wyszyńskiego w Warszawie. Redaktorka kwartalnika „Fraza”. Członkini zespołu Archiwum Kobiet i komitetu redakcyjnego serii wydawniczej Lupa Obscura (IBL PAN). 